\title{
Childhood Diarrhoea in the Eastern Mediterranean Region with Special Emphasis on Non-Typhoidal Salmonella at the Human-Food Interface
}

\author{
Ali Harb ${ }^{1,2}$ (D), Mark O’Dea ${ }^{1}$, Sam Abraham ${ }^{1}$ (D) and Ihab Habib 1,3,*(D) \\ 1 College of Science, Health, Education and Engineering, Murdoch University, Perth 6150, Australia; \\ aliharb8@yahoo.com (A.H.); m.o'dea@murdoch.edu.au (M.O.); s.abraham@murdoch.edu.au (S.A.) \\ 2 Thi-Qar Public Health Division, Ministry of Health, Thi-Qar 64007, Iraq \\ 3 High Institute of Public Health, Alexandria University, Alexandria 21516, Egypt \\ * Correspondence: i.habib@murdoch.edu.au; Tel.: +61-89-360-2434
}

Received: 12 April 2019; Accepted: 1 May 2019; Published: 6 May 2019

\begin{abstract}
Diarrhoeal disease is still one of the most challenging issues for health in many countries across the Eastern Mediterranean region (EMR), with infectious diarrhoea being an important cause of morbidity and mortality, especially in children under five years of age. However, the understanding of the aetiological spectrum and the burden of enteric pathogens involved in diarrhoeal disease in the EMR is incomplete. Non-typhoidal Salmonella (NTS), the focus of this review, is one of the most frequently reported bacterial aetiologies in diarrhoeal disease in the EMR. Strains of NTS with resistance to antimicrobial drugs are increasingly reported in both developed and developing countries. In the EMR, it is now widely accepted that many such resistant strains are zoonotic in origin and acquire their resistance in the food-animal host before onward transmission to humans through the food chain. Here, we review epidemiological and microbiological aspects of diarrhoeal diseases among children in the EMR, with emphasis on the implication and burden of NTS. We collate evidence from studies across the EMR on the zoonotic exposure and antimicrobial resistance in NTS at the interface between human and foods of animal origin. This review adds to our understanding of the global epidemiology of Salmonella with emphasis on the current situation in the EMR.
\end{abstract}

Keywords: Eastern Mediterranean region; non-typhoidal Salmonella; zoonoses; child diarrhoea; enteropathogens

\section{Background}

Worldwide, diarrhoeal diseases accounted for $8 \%$ of all deaths in children under five years of age in 2016, and this translates to over 1300 young children dying each day or approximately 480,000 children a year [1]. The incidence of diarrhoeal infections among children in the Eastern Mediterranean region (EMR) continues to pose a significant public health challenge in countries across the region. For the purpose of this review, we utilized the regional classification set by the World Health Organization (WHO), and as such, the EMR encompasses the Islamic Republic of Afghanistan (Afghanistan), Djibouti, Somalia, Republic of Yemen (Yemen), Arab Republic of Egypt (Egypt), Islamic Republic of Iran (Iran), Iraq, Jordan, Lebanon, Libya, Morocco, Pakistan, Palestine, Sudan, Syrian Arab Republic (Syria), Tunisia Bahrain, Kuwait, Oman, Qatar, Saudi Arabia, and the United Arab Emirates (UAE). The proportion of paediatric diarrhoea cases has increased over time in several countries in the EMR, as in Iraq-from 14.9\% in 1997 to $21.3 \%$ in 2000 [2,3] - and Iran, from 10.3\% to 19.6\% between 2008 and 2010 [4,5]. In Egypt, the incidence of diarrhoea in children has declined from $44 \%$ to $23.6 \%$ based on reports between 1999 and 2005 [6,7]. Diarrhoea attributed disability-adjusted life years (DALYs) among children under five years of age in the EMR regions were estimated to be 6,058,681 
$(4,045,101-8,618,353)[8]$. Across the 22 countries in the EMR, the highest rates of diarrhoea-attributed mortality among children younger than five years were reported in Somalia, Afghanistan, Djibouti, Iraq, Syria, Yemen, Sudan, Egypt and Tunisia [8,9].

Several countries in the EMR suffer from fragile health care systems, of which Iraq is an example. Several generations of Iraqi children born since the early 1990s have faced adverse conditions negatively impacting their nutrition and health as a result of decades of wars, sanctions and political instability [10]. Diarrhoeal disease is a leading cause of morbidity and mortality among Iraqi children younger than five years [10,11]. The period between 1994 and 1999 witnessed the highest rate of diarrhoea-attributed deaths in Iraq, and in the EMR as a whole, as diarrhoea was a common cause of death in children under five years old; it was responsible for $43.4 \%$ of deaths in children aged 2-5 years [11]. Additionally, the 2004 survey of the United Nations International Children's Emergency Fund (UNICEF) in partnership with the Government of Iraq indicated that approximately $90 \%$ of children under the age of five years visited hospitals due to diarrhoea [12]. In this former survey, diarrhoea and acute respiratory infection accounted for $70 \%$ of childhood deaths, but the fatality rate due to diarrhoeal illnesses was higher than those caused by respiratory infection [12].

\section{Epidemiological Aspects of Diarrhoeal Diseases Among Children in the EMR}

The majority of diarrhoea infections in children occur during the summer months in countries with a hot and dry climate $[13,14]$. It has been noted that enteric illnesses in temperate latitudes have a seasonal pattern, with the highest incidence of diseases during the summer months [15]. This is consistent with published evidence of a positive correlation between gastrointestinal infection with enteric pathogens and the increase in ambient temperature [16,17]. Several epidemiological studies confirm the role of age and immune response as important triggers to infectious diarrhoea in children $[18,19]$. Children below five years of age are significantly more susceptible to diarrhoeal illnesses compared with other age groups [14,18]. In Iraq, a study by Siziya and colleagues (2009) of the prevalence of diarrhoea in 14,676 children less than five years of age revealed that $21.3 \%$ of the children had diarrhoea in the two weeks preceding the survey. Based on the aforementioned survey, a history of diarrhoea was positively associated with lower socioeconomic status and a lack of access to clean sources of water [2]. A hospital-based study in Iraq reported a prevalence of diarrhoea in $63.5 \%$ of children at three government referral paediatric hospitals in Baghdad [20]. The authors also suggested that this high prevalence rate is likely due to economic collapse, poor sanitation, lack of safe water and inadequate provision of health care [20].

Paediatric diarrhoea has an important financial and productivity impact on the livelihood of families in different countries across the EMR [14,21]. In the United Arab Emirates, Howidi et al. [22] estimated an average cost of $\$ 64$ for expenses spent dealing with medical care per diarrhoeal episode in children. In Oman, a study by Al Awaidy et al. [23] revealed that the total cost of hospitalization due to diarrhoea (direct medical costs) was estimated at $\$ 539$ per child for three hospital days, totalling $\$ 1.8$ million per year for all outpatient and hospital settings in the country. 


\section{Microbiological Aspects of Diarrhoeal Diseases Among Children in the EMR}

The prevalence of enteropathogens in child diarrhoeal illnesses throughout the EMR is difficult to precisely assess due to variations in geographical settings, a lack of harmonization in sampling approaches and study designs and varying laboratory techniques and methods used across different studies, even within the same country $[24,25]$. Table 1 provides a descriptive summary of various studies reporting the occurrence of major etiological agents responsible for paediatric diarrhoea in different countries across the region. Data on enteric pathogens implicated in diarrhoea among children in the EMR are still limited.

In Iraq, little is known about the causative agents of diarrhoea in children. However, a prospective hospital-based study has shown that Entamoeba histolytica is responsible for approximately $85 \%$ of diarrhoea infections, and the same study also reported that non-typhoidal Salmonella spp. and Shigella were isolated from $42 \%$ of cases in children under five years of age [26]. In Saudi Arabia, cross-sectional studies have investigated the prevalence of pathogen-induced diarrhoea in faecal samples of children from hospitals and outpatient clinics in different localities. Among the different enteric pathogens found in these studies, rotavirus, Salmonella and Giardia lamblia were the most prevalent [27-29]. Studies conducted in Bahrain [30], Kuwait [31] and Oman [32] (Table 1) shared some common findings, with rotavirus and adenovirus found to be the major viral causes and Salmonella and Shigella found to be the most common bacterial causes involved in cases of child diarrhoea [31,32]. The authors also observed that symptoms associated with bacterial gastroenteritis were more severe compared to those of a viral nature. In Qatar, noroviruses have been implicated as the predominant viral pathogen associated with severe diarrhoea in children [33]. Microbiological studies on bacterial diarrhoeal illness among hospitalized children in Pakistan [34], Egypt [35,36], Iran [24], Palestine [37], Djibouti [38] and Somalia [39] reported that the main etiologic agents were Campylobacter, Salmonella, E. coli and Shigella. Clinical findings in these studies varied according to the aetiology of diarrhoea; however, abdominal pain, vomiting, fever and dehydration were seen in a majority of cases, and the highest incidence rates were commonly reported in the summer months.

In Libya [40], Sudan [25] and Tunisia [41], the molecular screening of the aetiology of acute diarrhoea among young children has revealed that the major viral agents identified were rotavirus and norovirus, the most frequently diagnosed bacterial pathogens were Salmonella spp. and E. coli and the most commonly detected parasites were Giardia lamblia and Entamoeba histolytica. Overall, the above reported studies across different countries in the EMR (Table 1) suggest that knowledge of the aetiology of diarrhoea is important for guiding future epidemiological surveillance and for the implementation of evidence-based public health measures to prevent and control this disease syndrome. Salmonella has been featured as one of the leading bacterial causes commonly detected in child diarrhoeal cases across the EMR. In the following section of this review, we will elucidate the state of epidemiological and microbiological features of non-typhoidal Salmonella (NTS) implicated in acute paediatric gastroenteritis in children in this region. 
Table 1. Distribution of different pathogens from diarrhoeal stool samples among children across countries in the Eastern Mediterranean region.

\begin{tabular}{|c|c|c|c|c|c|c|c|}
\hline \multirow{2}{*}{ Country/Locality } & \multirow{2}{*}{$\begin{array}{c}\text { Study } \\
\text { Period/Month }\end{array}$} & \multirow{2}{*}{ Population/Age } & \multirow{2}{*}{$\begin{array}{l}\text { No. of Stool } \\
\text { Samples }\end{array}$} & \multicolumn{3}{|c|}{ Prevalence of Enteropathogens } & \multirow{2}{*}{ Reference } \\
\hline & & & & Virus (\%) & Bacteria (\%) & Parasite (\%) & \\
\hline Bahrain & 20 & Children $<15$ years & 805 & $\begin{array}{l}\text { Rotavirus (13.9) } \\
\text { Adenovirus (0.6) }\end{array}$ & $\begin{array}{c}\text { Salmonella spp. (5.7) } \\
\text { Shigella spp. (3.2) } \\
\text { Campylobacter jejuni (1.6) } \\
\text { Enteropathogenic } \\
\text { Escherichia coli (E. coli) (0.5) }\end{array}$ & ND (not detected) & [30] \\
\hline Djibouti & 1 & Children $<16$ years & 209 & ND & $\begin{array}{c}\text { Enteroadherent E. coli (EAEC) (10.6) } \\
\text { Enterotoxigenic E. coli (ETEC) (11.0) } \\
\text { Enteropathogenic E. coli (EPEC) (7.7) } \\
\text { Shigella spp. (7.7) } \\
\text { Salmonella spp. }(2.9) \\
\text { Campylobacter jejuni/coli (3.3) } \\
\text { Aeromonas hydrophila (3.3) }\end{array}$ & ND & [38] \\
\hline Egypt/Alexandria & Not described & $\begin{array}{l}\text { Children mean age } 9.8 \\
\text { months }\end{array}$ & 880 & ND & $\begin{array}{l}\text { Campylobacter spp. (17.2) } \\
\text { Salmonella spp. (3) } \\
\text { Shigella spp. (2) }\end{array}$ & ND & [35] \\
\hline Egypt/Fayoum & 2 & Children $<5$ years & 356 & Rotavirus (17) & $\begin{array}{c}\text { Enterotoxigenic E. coli (ETEC) (10.8) } \\
\text { Campylobacter spp. (5.6) } \\
\text { Shigella spp. (2.0) } \\
\text { Salmonella spp. (0.6) } \\
\text { Aeromonas hydrophila (1.1) } \\
\text { Vibrio fluvialis }(0.6)\end{array}$ & Cryptosporidium (10.7) & [36] \\
\hline Iran/Tehran & 24 & Children $<5$ years & 1078 & ND & $\begin{array}{c}\text { Shigella spp (26.7) } \\
\text { Shiga-like toxin producing E. coli (STEC) } \\
\text { (18.9) } \\
\text { Enteroaggregative E. coli (EAEC) (16.6) } \\
\text { Enteropathogenic E. coli (EPEC) (12.6) } \\
\text { Campylobacter spp. (10.8) } \\
\text { Salmonella spp. (7.6) } \\
\text { Enterotoxigenic E. coli (ETEC) (6.8) }\end{array}$ & ND & [24] \\
\hline Iraq/Baghdad & Not described & Children $<10$ years & 1500 & ND & $\begin{array}{l}\text { Salmonella spp. (4.28) } \\
\text { Shigella spp. (2.14) }\end{array}$ & $\begin{array}{c}\text { Entamoeba histolytica } \\
(83.58)\end{array}$ & [28] \\
\hline
\end{tabular}


Table 1. Cont.

\begin{tabular}{|c|c|c|c|c|c|c|c|}
\hline \multirow{2}{*}{ Country/Locality } & \multirow{2}{*}{$\begin{array}{c}\text { Study } \\
\text { Period/Month }\end{array}$} & \multirow{2}{*}{ Population/Age } & \multirow{2}{*}{$\begin{array}{l}\text { No. of Stool } \\
\text { Samples }\end{array}$} & \multicolumn{3}{|c|}{ Prevalence of Enteropathogens } & \multirow{2}{*}{ Reference } \\
\hline & & & & Virus $(\%)$ & Bacteria (\%) & Parasite (\%) & \\
\hline Jordan/Irbid & 12 & Children $<12$ years & 265 & Rotavirus (32.5) & $\begin{array}{c}\text { Enteropathogenic E. coli }(12.8) \\
\text { Enteroaggregative E. coli }(10.2) \\
\text { Enterotoxigenic E. coli }(5.7) \\
\text { Shigella spp. }(4.9) \\
\text { Salmonella spp. }(4.5) \\
\text { Campylobacter jejuni/coli }(1.5) \\
\text { Enteroinvasive E. coli }(1.5)\end{array}$ & $\begin{array}{c}\text { Entamoeba histolytica (4.9) } \\
\text { Cryptosporidium spp. }(1.5) \\
\text { Giardia lamblia (0.8) }\end{array}$ & [42] \\
\hline Kuwait & 15 & Children (not described) & 621 & $\begin{array}{l}\text { Rotavirus (45.0) } \\
\text { Adenovirus (4.0) }\end{array}$ & $\begin{array}{c}\text { Salmonella spp. (24) } \\
\text { Enterotoxigenic E. coli (9) } \\
\text { Campylobacter jejuni (7) } \\
\text { Enteropathogenic E. coli (7) } \\
\text { Shigella (4) }\end{array}$ & ND & [31] \\
\hline Libya/Tripoli & 8 & Children $<5$ years & 239 & $\begin{array}{l}\text { Norovirus (15.5) } \\
\text { Rotavirus (13.4) } \\
\text { Adenovirus (7.1) } \\
\text { Astrovirus (1.7) }\end{array}$ & $\begin{array}{c}\text { E. coli (11.2) } \\
\text { Salmonella spp. }(9.7) \\
\text { Shigella spp. }(0.8) \\
\text { Campylobacter spp. }(2.9) \\
\text { Aeromonas spp. }(4.2) \\
\text { Cryptosporidium spp. }(2.1)\end{array}$ & $\begin{array}{l}\text { Entamoeba histolytica }(0.8) \\
\quad \text { Giardia lamblia }(1.3)\end{array}$ & [40] \\
\hline Morocco/Rabat & 13 & Children $<5$ years & 122 & $\begin{array}{c}\text { Rotavirus }(17.2) \\
\text { Astrovirus }(4.9) \\
\text { Hepatitis A (0.8) } \\
\text { Norovirus (0.8) } \\
\end{array}$ & $\begin{array}{c}\text { E. coli (58.2) } \\
\text { Shigella spp. (7.4) } \\
\text { Salmonella spp. }(4.1) \\
\text { Campylobacter spp. (4.1) }\end{array}$ & $\begin{array}{l}\text { Giardia intestinalis }(0.8) \\
\text { Entamoeba histolytica }(0.8)\end{array}$ & [43] \\
\hline Oman/Muscat & 24 & Children $<5$ years & 217 & $\begin{array}{l}\text { Rotavirus (31.0) } \\
\text { Adenovirus (4.0) }\end{array}$ & $\begin{array}{c}\text { E. coli (10) } \\
\text { Shigella (7) } \\
\text { Campylobacler spp. (2) } \\
\text { Salmonella spp. (2) }\end{array}$ & $\begin{array}{c}\text { Giardia lamblia (11), } \\
\text { Entamoeba histolytica }(9)\end{array}$ & [32] \\
\hline $\begin{array}{l}\text { Pakistan/Karachi } \\
\text { and Rawalpindi }\end{array}$ & 24 & Children $<3$ years & 402 & Rotavirus (8.2) & $\begin{array}{l}\text { Enteropathogenic E. coli (EPEC) (32.8) } \\
\text { Enterotoxigenic E. coli (ETEC) (14.2) } \\
\text { Shigella spp. (3.2) } \\
\text { Salmonella spp. (2) }\end{array}$ & ND & [34] \\
\hline Palestine/Gaza & 12 & Children $<12$ years & 300 & ND & $\begin{array}{c}\text { Enterohemorrhagic E. coli (8.3) } \\
\text { Shigella spp. (6.7) } \\
\text { Campylobacter jejuni (5) } \\
\text { Salmonella spp. (4) } \\
\text { Yersinia enterocolitica (2.7) } \\
\text { Aeromonas spp. (4.7) } \\
\text { Plesiomonas spp. (1.3) }\end{array}$ & ND & [37] \\
\hline
\end{tabular}


Table 1. Cont

\begin{tabular}{|c|c|c|c|c|c|c|c|}
\hline \multirow{2}{*}{ Country/Locality } & \multirow{2}{*}{$\begin{array}{c}\text { Study } \\
\text { Period/Month }\end{array}$} & \multirow{2}{*}{ Population/Age } & \multirow{2}{*}{$\begin{array}{l}\text { No. of Stool } \\
\text { Samples }\end{array}$} & \multicolumn{3}{|c|}{ Prevalence of Enteropathogens } & \multirow{2}{*}{ Reference } \\
\hline & & & & Virus $(\%)$ & Bacteria (\%) & Parasite (\%) & \\
\hline Qatar & 6 & Children (not described) & 288 & $\begin{array}{c}\text { Norovirus (28.5) } \\
\text { Rotavirus (10.4) } \\
\text { Adenovirus (6.25) } \\
\text { Astrovirus (0.30) } \\
\end{array}$ & $\begin{array}{c}\text { Salmonella spp. (8) } \\
\text { Escherichia coli (3) } \\
\text { Shigella spp. (1.5) } \\
\text { Campylobacter spp. (1.5) }\end{array}$ & ND & [33] \\
\hline $\begin{array}{c}\text { Saudi } \\
\text { Arabia/Eastern } \\
\text { Province }\end{array}$ & 19 & Children (not described) & 853 & Rotavirus (11.5) & $\begin{array}{l}\text { Salmonella spp. (34) } \\
\text { Shigella spp. (14.7) }\end{array}$ & $\begin{array}{l}\text { Entamoeba histolytica (13.5) } \\
\text { Giardia intestinalis (10.4) }\end{array}$ & [27] \\
\hline $\begin{array}{c}\text { Saudi } \\
\text { Arabia/Jeddah }\end{array}$ & 12 & Children $<5$ years & 576 & Rotavirus (34.6) & $\begin{array}{c}\text { E. coli (13) } \\
\text { Klebsiella pneumoniae (4) } \\
\text { Salmonella spp. (3) } \\
\text { Shigella flexneri (2.6) }\end{array}$ & $\begin{array}{c}\text { Giardia lamblia }(3.1) \\
\text { Entamoeba histolytica }(2.2) \\
\text { Trichuris trichiura }(0.7) \\
\text { Hymenolepis nana }(0.7) \\
\text { Ascaris lumbricoides }(0.7)\end{array}$ & [28] \\
\hline $\begin{array}{l}\text { Saudi } \\
\text { Arabia/Najran } \\
\text { region }\end{array}$ & 9 & Children $<5$ years & 326 & $\begin{array}{l}\text { Rotavirus (17.2) } \\
\text { Adenovirus (3.7) } \\
\text { Astrovirus (1.2) }\end{array}$ & $\begin{array}{l}\text { Salmonella spp. (8.6) } \\
\text { Shigella spp. (2.1) }\end{array}$ & $\begin{array}{c}\text { Giardia lamblia }(0.9) \\
\text { Entamoeba histolytica }(0.3)\end{array}$ & [29] \\
\hline $\begin{array}{l}\text { Somalia } \\
\text { Mogadishu }\end{array}$ & 12 & Children $<14$ years & 1667 & Rotavirus (25) & $\begin{array}{c}\text { Enterotoxigenic E. coli (ETEC) (11) } \\
\text { Shigella spp. (9) } \\
\text { Campylobacter jejuni (8) } \\
\text { Vibrio cholerae non-O1 (6) } \\
\text { Salmonella spp. (4) } \\
\text { Aeromonas hydrophila (9) } \\
\text { Plehnwnas shigelloides (2) }\end{array}$ & $\begin{array}{l}\text { Giardia intestinalis (8) } \\
\text { Entamoeba histolytica (2) }\end{array}$ & [39] \\
\hline Sudan/Khartoum & 12 & Children $<5$ years & 437 & Rotavirus A (22) & $\begin{array}{c}\text { Enteroaggregative E. coli (EAEC) (21) } \\
\text { Enteropathogenic E. coli (EPEC) (14) } \\
\text { Enterotoxigenic E. coli (ETEC) (9) } \\
\text { Enteroinvasive E. coli (EIEC) (4) } \\
\text { Shigella sonnei (3) } \\
\text { Shigella flexneri (4) } \\
\text { Shigella dysenteriae (1) } \\
\text { Salmonella typhi (2) } \\
\text { Salmonella paratyphi C (1) } \\
\text { Campylobacter jejuni (3) }\end{array}$ & $\begin{array}{l}\text { Giardia intestinalis (11), } \\
\text { Entamoeba histolytica (5) }\end{array}$ & [25] \\
\hline Tunisia & 12 & Children $<5$ years & 124 & $\begin{array}{l}\text { Rotavirus (33.9) } \\
\text { Norovirus (8.9) }\end{array}$ & $\begin{array}{c}\text { Enteroaggregative E. coli (EAEC) (23.4) } \\
\text { Enteroinvasive E. coli (EIEC) (12.1) } \\
\text { Enteropathogenic E. coli (EPEC) (13.7) } \\
\text { Enterotoxigenic E. coli (ETEC) (21) } \\
\text { Enterohemoragic E. coli (EHEC) (1.6) } \\
\text { Salmonella spp. }(9.7)\end{array}$ & $\begin{array}{c}\text { Entamoeba coli }(1.6) \\
\text { Cryptosporidies }(1.6) \\
\text { Giardia lamblia }(0.8) \\
\text { Blastocystis hominis }(0.8)\end{array}$ & [41] \\
\hline
\end{tabular}




\section{Non-Typhoidal Salmonella (NTS)—The Pathogen, Exposure and Illness}

As of 2012, $t$ more than 2587 serovars of Salmonella enterica have been reported from all over the world, and almost all are able to cause illness in animals and humans including gastroenteritis and other acute infections [44]. Salmonella spp. are capable of adapting, growing and/or surviving in a various range of environments including temperatures as high as $54{ }^{\circ} \mathrm{C}$ or as low as $2{ }^{\circ} \mathrm{C}$, extracellular $\mathrm{pH}$ levels below 3.9 and up to 9.5 and salt concentrations up to $4 \% \mathrm{wv}-1 \mathrm{NaCl}$ [45-47]. Such exceptional characteristics can have a significant effect on the survival of Salmonella outside of the host organism and in food during processing, preparation, and storage [45,48]. In pure cultures, Salmonella spp. are normally inactivated by frozen storage at $-22^{\circ} \mathrm{C}$ in as few as 5 days [49]; however, freezing does not eliminate the pathogen from contaminated foods [50]. In addition to its survival in extreme conditions, the growth of this pathogen in non-host environments such as natural waters, wastewater sludge, soil and compost has also been reported in several studies [51,52].

There are two major clinical syndromes caused by Salmonella infection in human: the first is typhoid and paratyphoid fever, caused by S. Typhi and Paratyphi, which are highly adapted to the human host; and the second major clinical syndrome is the gastrointestinal disease caused by a large number of NTS serovars, which are predominantly found in animal reservoirs [53]. The most common mode of NTS infection in human is the ingestion of contaminated food or water [54,55]. Initial symptoms are characterized by an acute onset of fever and chills, nausea and vomiting, abdominal cramping and diarrhoea, and other nonspecific complaints including headache, myalgias, and arthralgias [56,57]. Gastroenteritis caused by NTS is usually self-limiting, lasting for 10 days or less, and may be grossly bloody [54]. Salmonella is excreted in faeces after infection, a process that may last for a median of 5 weeks; however, the excretion may be prolonged in young children [58,59]. In rare cases, NTS infections could develop atypical clinical syndromes of variable severity, including bacteraemia, endovascular infection and focal infection $[56,60]$. In developing countries, children with bacteraemia are more likely to have predisposing conditions, a higher risk for the incidence of meningitis and increased fatality rates compared to adults $[58,61]$.

\section{Implication of NTS in Diarrhoeal Illnesses in the EMR}

The global burden of NTS gastroenteritis is estimated to be 93.8 million human infections, with 155 thousand deaths and an average incidence rate of 1.14 episodes $/ 100,000$ persons [62]. This reflects the enormous burden of the disease in both industrialized and developing countries [63]. For the WHO-defined EMR, the median incidence rate of NTS is 1610 illnesses, with 0.6 deaths per 100,000 persons [64]. The incidence rate of salmonellosis varies substantially between countries across the EMR and is influenced largely by the absence of systematic, harmonized national and regional surveillance and reporting systems. An epidemiological survey in Qatar spanning eight years (2004 to 2012) reported that the incidence rate of reported NTS associated illnesses ranged between 12.3 and 18.1 cases per 100,000 inhabitants, with most reported NTS cases occurring in children under the age of five [65]. In Lebanon, the Department of Epidemiologic Surveillance data from 2001 to 2013 indicated that the annual incidence rate of reported salmonellosis was 13.3 per 100,000 individuals, with an increasing trend of the number of NTS cases between 2009 and 2013 [66]. In Jordan, the reported rate of human salmonellosis is alarmingly higher than what is reported elsewhere across the EMR, with a notification rate of 124 cases per 100,000 persons, as reported in a study from 2003 to 2004 [67]. Significant associations between climatic factors and NST infections have been reported in Iraq [68], Jordan [42], Tunisia [69], Iran [24], Saudi Arabia [70] and Qatar [33]. It has been documented that ambient temperatures contribute directly to Salmonella multiplication in foods, water and contaminated environments and thus propagate the likelihood of infection [15,71].

Few studies have been carried out to elucidate the epidemiology of gastrointestinal salmonellosis in the EMR, particularly on children. The prevalence rates of NTS range from as low as $0.2 \%$ to as high as $34 \%[27,39]$, with the highest reported age-related prevalence usually among children under the age of five (Table 2). Published studies reporting the rates of NTS in the EMR countries are summarised in Table 2. Studies from Iraq (Mosul) [68], Iran (Tehran) [72], Saudi Arabia [27], Kuwait [31], Morocco (Marrakesh) [43] and Yemen [73] reveal a noteworthy high incidence rate (15\% to 34\%) of NTS (Table 2). 
Table 2. Prevalence of Salmonella detected in children with acute diarrhoea in the Eastern Mediterranean region.

\begin{tabular}{|c|c|c|c|c|c|c|c|c|}
\hline Country/Locality & $\begin{array}{c}\text { Study } \\
\text { Period/Month }\end{array}$ & Population/Age & Source of Cases & Methods & $\begin{array}{l}\text { Number of Acute } \\
\text { Diarrhoeal Cases }\end{array}$ & $\begin{array}{c}\text { Prevalence of } \\
\text { Salmonella Infected (\%) }\end{array}$ & $\begin{array}{c}\text { Predominate S. } \\
\text { Serovar }\end{array}$ & References \\
\hline Bahrain & 24 & Children $<15$ years & Hospital admissions & Salmonella culture (stool) & 805 & $46(5.7)$ & Typhimurium & {$[30]$} \\
\hline Djibouti & 1 & Children $<16$ years & Health centres & Salmonella culture (stool) & 209 & $6(2.9)$ & NS (not specified) & {$[38]$} \\
\hline Egypt/Aswan & Not described & $\begin{array}{l}\text { Children (not } \\
\text { described) }\end{array}$ & $\begin{array}{l}\text { Outpatients and } \\
\text { inpatients }\end{array}$ & Salmonella culture (stool) & 151 & $11(7)$ & NS & [74] \\
\hline Egypt/Cairo & Not described & Children $<5$ years & Hospital admissions & Salmonella culture (stool) & 356 & $5(1.4)$ & NS & [75] \\
\hline Egypt/Fayoum & 2 & Children $<5$ years & Hospital admissions & Salmonella culture (stool) & 356 & $2(0.6)$ & & {$[36]$} \\
\hline Iran & 36 & Children $<5$ years & $\begin{array}{l}\text { Children hospitals } \\
\text { admissions }\end{array}$ & Salmonella culture and PCR & 555 & $42(7.6)$ & NS & [24] \\
\hline Iran/Tehran & 108 & Children $<14$ years & Hospital admissions & Salmonella culture (stool) & 2487 & $700(28.14)$ & NS & [72] \\
\hline Iran/Tehran & 24 & Children $<12$ years & $\begin{array}{l}\text { Paediatric hospital } \\
\text { admissions }\end{array}$ & Salmonella culture (stool) & 5900 & $139(2.4)$ & $\begin{array}{l}\text { Typhimurium } \\
\text { Enteritidis }\end{array}$ & [76] \\
\hline Iraq/Mosul & Not described & Children $<7$ years & $\begin{array}{l}\text { Paediatric hospital } \\
\text { admissions }\end{array}$ & Salmonella culture (stool) & 111 & $17(15)$ & $\begin{array}{l}\text { Typhimurium } \\
\text { Worthington }\end{array}$ & [68] \\
\hline Iraq/Baghdad & Not described & Children $<10$ years & $\begin{array}{l}\text { Paediatric hospital } \\
\text { admissions }\end{array}$ & Salmonella culture (stool) & 420 & $18(4.7)$ & NS & [26] \\
\hline Jordan/Irbid & 12 & Children $<12$ years & Hospitalized children & Salmonella culture (stool) & 265 & $12(4.5)$ & NS & [42] \\
\hline Jordan & 48 & $\begin{array}{l}\text { Children (Not } \\
\text { described) }\end{array}$ & Hospital admissions & Salmonella culture (stool) & 1400 & $150(10.7)$ & NS & [77] \\
\hline Kuwait & 15 & $\begin{array}{l}\text { Children (Not } \\
\text { described) }\end{array}$ & Hospitalized children & Salmonella culture (stool) & 621 & $149(24)$ & NS & [31] \\
\hline Libya/Zliten & 12 & Children $<12$ years & Hospital admissions & Salmonella culture (stool) & 169 & $23(13.6)$ & $\begin{array}{c}\text { Heidelberg } \\
\text { Enteritidis }\end{array}$ & [78] \\
\hline Morocco/Marrakesh & 12 & Children $<15$ years & $\begin{array}{l}\text { Patient children in } \\
\text { household }\end{array}$ & Salmonella culture (stool) & 390 & $127(32 \cdot 56)$ & $\begin{array}{l}\text { Salmonella group A } \\
\text { Salmonella group B } \\
\text { Salmonella group C } \\
\text { Salmonella group D }\end{array}$ & [79] \\
\hline Morocco/Rabat & 13 & Children $<5$ years & Hospital admissions & Salmonella culture (stool) & 122 & $5(4.1)$ & NS & [43] \\
\hline Oman/Muscat & 24 & Children $<5$ years & Hospital admissions & Salmonella culture (stool) & 217 & $5(2)$ & NS & [32] \\
\hline
\end{tabular}


Table 2. Cont

\begin{tabular}{|c|c|c|c|c|c|c|c|c|}
\hline Country/Locality & $\begin{array}{c}\text { Study } \\
\text { Period/Month }\end{array}$ & Population/Age & Source of Cases & Methods & $\begin{array}{l}\text { Number of Acute } \\
\text { Diarrhoeal Cases }\end{array}$ & $\begin{array}{c}\text { Prevalence of } \\
\text { Salmonella Infected (\%) }\end{array}$ & $\begin{array}{c}\text { Predominate S. } \\
\text { Serovar }\end{array}$ & References \\
\hline $\begin{array}{l}\text { Pakistan/Karachi } \\
\text { and Rawalpindi }\end{array}$ & 24 & Children $<3$ years & Hospital admissions & Salmonella culture (stool) & 402 & $8(2)$ & NS & {$[34]$} \\
\hline Palestine/Gaza & 12 & Children $<12$ years & Hospital admissions & Salmonella culture (stool) & 300 & $12(4)$ & NS & {$[37]$} \\
\hline Qatar & 5 & $\begin{array}{l}\text { Children (Not } \\
\text { described) }\end{array}$ & Hospital admissions & Salmonella culture (stool) & 288 & $23(8)$ & NS & [33] \\
\hline $\begin{array}{c}\text { Saudi } \\
\text { Arabia/Yanbu }\end{array}$ & 4 & $\begin{array}{c}\text { Children (Not } \\
\text { described) }\end{array}$ & Hospital admissions & Salmonella culture (stool) & 136 & $15(11)$ & $\begin{array}{c}\text { Typhimurium } \\
\text { Enteritidis } \\
\text { Virchow }\end{array}$ & {$[80]$} \\
\hline $\begin{array}{c}\text { Saudi } \\
\text { Arabia/Eastern } \\
\text { Province }\end{array}$ & 19 & $\begin{array}{l}\text { Children (Not } \\
\text { described) }\end{array}$ & Hospital admissions & Salmonella culture (stool) & 853 & $290(34)$ & NS & [27] \\
\hline $\begin{array}{c}\text { Saudi } \\
\text { Arabia/South } \\
\text { Jeddah }\end{array}$ & 12 & Children $<16$ years & Hospital admissions & Salmonella culture (stool) & 367 & $56(15.3)$ & NS & {$[70]$} \\
\hline Somalia/Mogadishu & 12 & Children $<14$ years & Hospital admissions & Salmonella culture (stool) & 1667 & $4(0.2)$ & NS & [39] \\
\hline Sudan/Khartoum & 12 & Children $<5$ years & Children in rural area & Salmonella culture (stool) & 437 & $3(0.7)$ & Enteritidis & {$[81]$} \\
\hline Tunisia/Tunis & 48 & Children $1-15$ years & $\begin{array}{c}\text { Paediatric and health } \\
\text { centres }\end{array}$ & Salmonella culture (stool) & 115 & $11(9.5)$ & $\begin{array}{c}\text { Enteritidis } \\
\text { Anatum }\end{array}$ & [69] \\
\hline Yemen/Thamar & 12 & $\begin{array}{l}\text { Children (Not } \\
\text { described) }\end{array}$ & Hospital admissions & $\begin{array}{l}\text { Salmonella culture (stool, } \\
\text { blood, urine) }\end{array}$ & 460 & $73(15.9)$ & $\begin{array}{c}\text { Typhimurium } \\
\text { Enteritidis }\end{array}$ & {$[73]$} \\
\hline
\end{tabular}


Several published studies (Table 2) indicate that the most widely reported serovars associated with acute diarrhoeal disease across the EMR are the Salmonella serovar Typhimurium and Salmonella serovar Enteritidis $[73,76,80]$. Similar to the situation in EMR, $S$. Typhimurium followed by $S$. Enteritidis are also the top-ranked serovars involved in human diarrhoeal illnesses across Africa, North America and Oceania (Australia and New Zealand) [82]. In contrast, $S$. Enteritidis is more frequently reported than S. Typhimurium in human clinical isolates in Europe, Asia and Latin America [83].

The difference in Salmonella prevalence and the diversity of NTS serovars among humans is dynamic in nature, and it is not surprising to capture variations between countries. Such variations might be attributed to several factors impacting NTS levels in food and water, which play a major role in human exposure to infection [84]. Among these factors are climate, food-animal production practices, the level of spread of specific serotypes in environmental reservoirs and the availability of vaccination programs in food animals. Eggs and poultry products have been described as the main vehicles for the transmission of human salmonellosis, accounting for the majority of foodborne outbreaks $[84,85]$.

\section{NTS and the Risk of Zoonotic Exposure from Chicken Meat Products}

Several studies in the EMR investigated the prevalence of NTS in local and imported chicken meat, as summarised in Table 3. Rates of Salmonella contamination vary between countries due to a number of factors including the source and type of sample, slaughterhouse sanitation, the level of cross-contamination at the retail level and the detection methods employed $[76,86]$. In Iraq, Salmonella contamination was reported in $26 \%$ of fresh retail chicken meat samples $[87,88]$ and in $39 \%$ of raw and frozen chicken carcasses [89]. Studies in several EMR countries have identified low Salmonella prevalence rates in chicken meat, such as in Kuwait [90], Tunis/Tunisia [91], Saudi Arabia/Riyadh [92], and Egypt $[93,94]$. Several studies indicated that $S$. Typhimurium and $S$. Enteritidis were the most prevalent serovars in chicken meat in the EMR $[86,93,95,96]$. Interestingly, the two most commonly reported Salmonella serovars in human diarrhoeal illness are also the two commonly recovered serovars from chicken meat, highlighting the role of chicken meat as an important source of salmonellosis in this region. 
Table 3. Prevalence of Salmonella detected in chicken meat in the Eastern Mediterranean region.

\begin{tabular}{|c|c|c|c|c|c|}
\hline Country/Locality & Source of Samples & $\begin{array}{l}\text { No. Positive/No. Test } \\
\text { (\% Prevalence) }\end{array}$ & Methods & $\begin{array}{l}\text { Predominant } S . \\
\text { Serovars }\end{array}$ & Reference \\
\hline $\begin{array}{c}\text { Egypt/Dakahlia, } \\
\text { Gharbia, Damietta and } \\
\text { Kafr el-Sheikh }\end{array}$ & Chicken meat & $14 / 320(5)$ & Salmonella culture and PCR & $\begin{array}{l}\text { Typhimurium } \\
\text { Enteritidis } \\
\text { Infantis }\end{array}$ & [93] \\
\hline Egypt/Mansoura & $\begin{array}{l}\text { Chicken carcasses } \\
\text { Chicken drumsticks } \\
\text { Chicken gizzards } \\
\text { Chicken livers }\end{array}$ & $\begin{array}{c}8 / 50(16) \\
14 / 50(28) \\
16 / 50(32) \\
30 / 50(60)\end{array}$ & Salmonella culture and PCR & $\begin{array}{l}\text { Enteritidis } \\
\text { Typhimurium } \\
\text { Kentucky }\end{array}$ & [86] \\
\hline $\begin{array}{l}\text { Egypt/Minoufiya and } \\
\text { Cairo }\end{array}$ & Chicken meat & $6 / 100(6)$ & $\begin{array}{l}\text { Salmonella culture and matrix-assisted laser } \\
\text { desorption/ionization time-of-flight (MALDI-TOF) }\end{array}$ & $\begin{array}{l}\text { Typhimurium } \\
\text { Enteritidis }\end{array}$ & [94] \\
\hline Egypt/Zagazig & Chicken meat & $7 / 50(14)$ & Salmonella culture and PCR & Typhimurium & [97] \\
\hline Iran/Alborz & $\begin{array}{l}\text { Chicken meat } \\
\text { Chicken liver } \\
\text { Chicken heart } \\
\text { Chicken gizzard }\end{array}$ & $\begin{array}{l}58 / 200(29) \\
26 / 120(21.6) \\
17 / 120(14.1) \\
10 / 120(8.3)\end{array}$ & Salmonella culture & $\begin{array}{l}\text { Thompson } \\
\text { Enteritidis } \\
\text { Typhimurium }\end{array}$ & [87] \\
\hline Iran/Tehran & Chicken meat & $86 / 190(45)$ & Salmonella culture & $\begin{array}{l}\text { Thompson } \\
\text { Haardt } \\
\text { Enteritidis }\end{array}$ & [98] \\
\hline Iraq/Baghdad & Chicken meat & $39 / 100(39)$ & Salmonella culture & $\begin{array}{l}\text { Infantis } \\
\text { Enteritidis } \\
\text { Vichow }\end{array}$ & [89] \\
\hline Iraq/Mosul & Chicken meat & $21 / 81(26)$ & Salmonella culture & $\begin{array}{l}\text { Infantis } \\
\text { Zanzibar } \\
\text { Anatum }\end{array}$ & [88] \\
\hline Jordan/Irbid & Chicken meat & $91 / 104(87.5)$ & Salmonella culture and PCR & NS & [99] \\
\hline Jordan/Northern & $\begin{array}{l}\text { Chicken product } \\
\text { (shawarma) }\end{array}$ & $30 / 80(37.5)$ & Salmonella culture and PCR & $\begin{array}{l}\text { Paratyphi A } \\
\text { Cholerasuis } \\
\text { Pullorum }\end{array}$ & [100] \\
\hline Jordan/Northern & Chicken meat & $200 / 302(66)$ & Salmonella culture and PCR & $\begin{array}{l}\text { Enteritidis } \\
\text { Cholerasuis, }\end{array}$ & [101] \\
\hline
\end{tabular}


Table 3. Cont.

\begin{tabular}{|c|c|c|c|c|c|}
\hline Country/Locality & Source of Samples & $\begin{array}{l}\text { No. Positive/No. Test } \\
\text { (\% Prevalence) }\end{array}$ & Methods & $\begin{array}{l}\text { Predominant } S . \\
\text { Serovars }\end{array}$ & Reference \\
\hline Kuwait & Chicken carcasses & $11 / 180(6.1)$ & Salmonella culture & $\begin{array}{l}\text { Enteritidis } \\
\text { Infantis }\end{array}$ & {$[90]$} \\
\hline Libya/Tripoli & $\begin{array}{l}\text { Chicken product } \\
\text { (burgers) }\end{array}$ & $15 / 120(12.9)$ & Salmonella culture & NS & [102] \\
\hline Morocco/Tetouan & Chicken meat & $18 / 86(20.9)$ & Salmonella culture & $\begin{array}{c}\text { Kentucky } \\
\text { Typhimurium, } \\
\text { Enteritidis } \\
\text { Agona }\end{array}$ & [95] \\
\hline Pakistan/Hyderabad & Chicken meat & $38 / 100(38)$ & Salmonella culture & $\begin{array}{c}\text { Enteritidis } \\
\text { Typhimurium. }\end{array}$ & [103] \\
\hline Pakistan/Karachi & Chicken carcasses & $78 / 160(48.75)$ & Salmonella culture & $\begin{array}{c}\text { Enteritidis } \\
\text { Typhimurium }\end{array}$ & [96] \\
\hline Saudi Arabia/Riyadh & $\begin{array}{l}\text { Chicken liver } \\
\text { Chicken heart } \\
\text { Chicken spleen }\end{array}$ & $\begin{array}{c}209 / 3284(6.3) \\
107 / 2315(4.6) \\
45 / 899(5.0)\end{array}$ & Salmonella culture & $\begin{array}{l}\text { Enteritidis } \\
\text { Virchow }\end{array}$ & [92] \\
\hline Sudan/Khartoum & Chicken meat & 35/193 (18.13) & Salmonella culture & $\begin{array}{c}\text { Stanleyville } \\
\text { Kentucky } \\
\text { Virchow } \\
\text { Hadar } \\
\text { Typhimurium }\end{array}$ & [104] \\
\hline Syria & Chicken meat & $32 / 100(32)$ & Salmonella culture & NS & [105] \\
\hline Tunis & Chicken meat & $29 / 60(48.3)$ & Salmonella culture and PCR & $\begin{array}{l}\text { Typhimurium } \\
\text { Zanzibar } \\
\text { Orion }\end{array}$ & [106] \\
\hline Tunis/Tunisia & Chicken meat & $29 / 433(6.7)$ & Salmonella culture and PCR & $\begin{array}{l}\text { Kentucky } \\
\text { Anatum } \\
\text { Zanzibar }\end{array}$ & [91] \\
\hline $\begin{array}{l}\text { United Arab } \\
\text { Emirates/Dubai }\end{array}$ & Chicken meat & $28 / 60(46.67)$ & Salmonella culture & NS & [107] \\
\hline
\end{tabular}


To study the zoonotic transmission of NTS at the human-animal-food interface, it is important to employ the advances in molecular epidemiology tools. Pulsed-field gel electrophoresis (PFGE) and multiple-locus variable-number tandem repeat analysis (MLVA) have been widely considered to be the gold standard molecular subtyping and fingerprinting methods for tracking the source of Salmonella contamination [108,109]. However, in recent years, Whole Genome Sequencing (WGS) has become a powerful tool in elucidating transmission pathways [110]. For Salmonella, WGS provides a massive amount of data for research purposes along with the rapid acquisition of multilocus sequence types (MLST), serotypes and antimicrobial resistance gene data [111-113]. Sequence-based typing can also be used to obtain basic biological insights to explain the associations between isolates, thus providing added value to the source attribution [112-114]. In addition to its high discrimination ability, WGS could provide additional data about virulence determinants and genome evolution, and such results can be easily shared and communicated [115-117].

\section{Antimicrobial Resistance in NTS at the Interface between Human and Food of Animal Origin in the EMR}

Antimicrobial therapy is recommended in severe cases and/or cases of prolonged enteritis, meningitis, septicaemia and extra-intestinal complications associated with salmonellosis $[53,58,60]$. Antimicrobial resistance in NTS has increased in recent years worldwide, due to the widespread use of antimicrobial drugs in human and veterinary sectors, and poses an on-going threat to global public health [118-121]. The incidence of resistance to traditional antibiotics (e.g., ampicillin, tetracycline and streptomycin) is evident to be high in Salmonella isolates from foods of animal origin, especially poultry, in EMR countries $[86,87,98-120]$. This finding is highly concerning from a public health perspective, as many of these traditional (1st generation) antibiotics are still widely prescribed to treat diarrhoea in children and adults due to their low cost and availability in developing countries, including countries of the EMR [121,122]. Similar patterns of high resistance to these traditional antibiotics are also evident in Salmonella isolated from human enteric illnesses, especially in Iraq [68], Kuwait [31], Saudi Arabia [123], Jordan [77], Iran [76], Oman [124] and Libya [40].

Studies in Saudi Arabia [123], and Kuwait [125] reported frequent resistance to chloramphenicol in NTS isolated from childhood diarrhoea (although it is not approved for human use). Resistance to chloramphenicol in Salmonella is facilitated by type $A$ chloramphenicol acetyltransferase genes (catA1 and catA2) or by cassette-borne type B chloramphenicol acetyltransferase genes (catB2, catB3 or catB8) $[126,127]$. Furthermore, two new chloramphenicol/florfenicol exporter genes, cmlA9 and floR, have recently been identified for phenicol resistance genes in Salmonella isolates [121-128].

Resistance to nalidixic acid (NA) in Salmonella isolates from paediatric cases with enteritis was as high as $84.2 \%$ in a study in Libya [40] and was detected at a rate of $42.3 \%$ in a study in Iran [72]. There is an alarming concern over the increase in the resistance of NTS to ciprofloxacin and extended-spectrum cephalosporins [118,129], given the critical clinical relevance of these antimicrobials. Chromosomal mutations in the genes encoding topoisomerase II, gyrA and $g y r B$, and/or topoisomerase IV, $\operatorname{parC}$ and parE, accounting for resistance to quinolones/fluoroquinolones, are known to occur in Salmonella isolates [130]. More recently, various plasmid-mediated quinolone resistance (PMQR) genes including genes $q n r D$, $q n r A, q n r B$ and $q n r S$ variants, all of which code for DNA topoisomerase protecting proteins, as well as the genes qep $A$ and qep $A B$ coding for a quinolone-specific efflux pump, and the acetyltransferase aac(60)-Ib-cr, have been identified in Salmonella isolates [131-133]. In some EMR countries, the increase in resistance is rapid and considerable; in Libya, a study reported that $63.1 \%$ of human Salmonella isolates were ciprofloxacin-resistant [40].

Resistance to $\beta$-lactam antibiotics (penicillins, cephalosporins, and carbapenems) in Salmonella is mediated by a wide range of $\beta$-lactamase enzymes [134]. To date, genes coding for 13 different types of $\beta$-lactamases have been known in Salmonella. Among them, bla $a_{A A C} / b l a_{D H A} / b l a_{C M Y} / b l a_{T E M}$ genes are of particular importance as the first representative encoding of cephalosporinases that hydrolyse most $\beta$-lactamase except carbapenems [129]. Extended-spectrum cephalosporins are the antimicrobials of 
choice for invasive Salmonella treatment, especially in children where treatment with fluoroquinolones is not recommended [130]. A study by Rotimi et al. [135] observed resistance to cefotaxime and ceftriaxone among Salmonella spp. isolated from stool samples of patients with acute diarrhoea and septicaemia during 2003-2005 in Kuwait and United Arab of Emirates.

\section{Conclusions}

This review consolidates recent updates on the spectrum of enteric pathogens in the EMR region, with special emphasis on NTS. Among bacterial pathogens, NTS infections continue to pose a distressing public health concern, notably in children under five years old. The emergence of antimicrobial resistance in Salmonella strains present a great challenge at the human-food-environment interface in terms of the effective treatment of the infections caused by these strains. The EMR spans different countries with varying and evolving socio-economic statuses. Several countries in the EMR, notably Iraq, Yemen and Syria, are experiencing similar challenges as a result of fragile political situations and insecurity as well as sanitation, food safety, and food security issues and an influx of refugees. The public health system in several countries in the EMR is struggling to respond to the evolving burden of enteric illnesses due to the lack of surveillance of important enteric pathogens, such as Salmonella, at hospital, household and food chain levels and would benefit from a multi-dimensional research approach encompassing these levels. Bacterial infections and their antimicrobial resistance profiles should be monitored more closely across the EMR, especially in vulnerable groups such as children less than five years old. Studies focusing on investigating epidemiological and microbiological aspects of infectious diarrhoea in underprivileged communities/regions at the national level should be prioritized in future research.

Author Contributions: Conceptualization, I.H.; methodology, A.H.; writing—review \& editing, A.H., M.O., S.A., I.H.

Funding: This research received no external funding.

Conflicts of Interest: The authors declare no conflict of interest.

\section{References}

1. United Nations International Children's Emergency Fund. Diarrhoeal Diseases. UNICEF Data: Monitoring the Situation of Children and Women. 2018. Available online: https://ata.unicef.org/topic/child-health/ diarrhoeal-disease/ (accessed on 5 June 2018).

2. Siziya, S.; Muula, A.S.; Rudatsikira, E. Diarrhoea and acute respiratory infections prevalence and risk factors among under-five children in Iraq in 2000. Ital. J. Pediatr. 2009, 35, 8. [CrossRef]

3. Tawfeek, H.I.; Najim, N.H.; Al-Mashikhi, S. Studies on diarrhoeal illness among hospitalized children under 5 years of age in Baghdad during 1990-1997. East. Mediterr. Health J. 2002, 8, 181-188.

4. Kermani, N.A.; Jafari, F.; Mojarad, H.N.; Zali, M.R. Prevalence and associated factors of persistent diarrhoea in Iranian children admitted to a paediatric hospital. East. Mediterr. Health J. 2010, 16, 831-836. [CrossRef] [PubMed]

5. Kolahi, A.A.; Nabavi, M.; Sohrabi, M.R. Epidemiology of acute diarrheal diseases among children under 5 years of age in Tehran, Iran. Iran. J. Clin. Infect. Dis. 2008, 3, 193-198.

6. Deghedi, B.; Mahdy, N.H. Assessment of health and nutritional status of infants in relation to breast feeding practices in Karmouz area, Alexandria. J. Egypt. Public Health Assoc. 1999, 74, 567-600. [PubMed]

7. El-Gilany, A.H.; Hammad, S. Epidemiology of diarrhoeal diseases among children under age 5 years in Dakahlia, Egypt. East. Mediterr. Health J. 2005, 11, 762-775.

8. GBD 2015 Eastern Mediterranean Region Diarrhea Collaborators. Burden of diarrhea in the Eastern Mediterranean Region, 1990-2015: Findings from the Global Burden of Disease 2015 study. Int. J. Public Health 2018, 63 (Suppl. 1), 109-121. [CrossRef]

9. GBD Diarrhoeal Diseases Collaborators. Estimates of global, regional, and national morbidity, mortality, and aetiologies of diarrhoeal diseases: A systematic analysis for the Global Burden of Disease Study 2015. Lancet Infect. Dis. 2017, 17, 909-948. [CrossRef] 
10. Ahmed, S.; Klena, J.; Albana, A.; Alhamdani, F.; Oskoff, J.; Soliman, M.; Heylen, E.; Teleb, N.; Husain, T.; Matthijnssens, J. Characterization of human rotaviruses circulating in Iraq in 2008: Atypical G8 and high prevalence of P [6] strains. Infect. Genet. Evol. 2013, 16, 212-217. [CrossRef]

11. Awqati, N.A.; Ali, M.M.; Al-Ward, N.J.; Majeed, F.A.; Salman, K.; Al-Alak, M.; Al-Gasseer, N. Causes and differentials of childhood mortality in Iraq. BMC Pediatr. 2009, 9, 40. [CrossRef]

12. United Nations International Children's Emergency Fund. Evaluation of UNICEF Emergency Preparedness and Early Response in Iraq (September 2001-June 2003). 2004. Available online: https://www.unicef.org/ evaldatabase/files/Iraq_evaluation_FINAL_2006.pdf (accessed on 6 October 2004).

13. Musengimana, G.; Mukinda, F.K.; Machekano, R.; Mahomed, H. Temperature Variability and Occurrence of Diarrhoea in Children under Five-Years-Old in Cape Town Metropolitan Sub-Districts. Int. J. Environ. Res. Public Health 2016, 13, 859. [CrossRef] [PubMed]

14. Khoury, H.; Ogilvie, I.; El Khoury, A.C.; Duan, Y.; Goetghebeur, M.M. Burden of rotavirus gastroenteritis in the Middle Eastern and North African pediatric population. BMC Infect. Dis. 2011, 11, 9. [CrossRef] [PubMed]

15. Akil, L.; Ahmad, H.A.; Reddy, R.S. Effects of climate change on Salmonella infections. Foodborne Pathog. Dis. 2014, 11, 974-980. [CrossRef] [PubMed]

16. Mellor, J.E.; Levy, K.; Zimmerman, J.; Elliott, M.; Bartram, J.; Carlton, E.; Clasen, T.; Dillingham, R.; Eisenberg, J.; Guerrant, R.; et al. Planning for climate change: The need for mechanistic systems-based approaches to study climate change impacts on diarrheal diseases. Sci. Total Environ. 2016, 548-549, 82-90. [CrossRef] [PubMed]

17. Checkley, W.; Epstein, L.D.; Gilman, R.H.; Figueroa, D.; Cama, R.I.; Patz, J.A.; Black, R.E. Effect of El Nino and ambient temperature on hospital admissions for diarrhoeal diseases in Peruvian children. Lancet 2000, 355, 442-450. [CrossRef]

18. Gizaw, Z.; Woldu, W.; Bitew, B.D. Child feeding practices and diarrheal disease among children less than two years of age of the nomadic people in Hadaleala District, Afar Region, Northeast Ethiopia. Int. Breastfeed. J. 2017, 12, 24. [CrossRef] [PubMed]

19. Mihrete, T.S.; Getahun Asres Alemie, G.A.; Teferra, A.S. Determinants of childhood diarrhea among underfive children in Benishangul Gumuz Regional State, North West Ethiopia. BMC Pediatr. 2014, 14, 102.

20. Alaa, H.; Shah, S.A.; Khan, A.R. Prevalence of diarrhoea and its associated factors in children under five years of age in Baghdad, Iraq. Open J. Prev. Med. 2014, 4, 17-21. [CrossRef]

21. Sepanlou, S.G.; Malekzadeh, F.; Delavari, F.; Naghavi, M.; Forouzanfar, M.H.; Moradi-Lakeh, M.; Malekzadeh, R.; Poustchi, H.; Pourshams, A. Burden of Gastrointestinal and Liver Diseases in Middle East and North Africa: Results of Global Burden of Diseases Study from 1990 to 2010. Middle East J. Dig. Dis. 2015, 7, 201-215.

22. Howidi, M.; Al Kaabi, N.; El Khoury, A.C.; Brandtmüller, A.; Nagy, L.; Richer, E.; Haddadin, W.; Miqdady, M.S. Burden of acute gastroenteritis among children younger than 5 years of age-a survey among parents in the United Arab Emirates. BMC Pediatr. 2012, 12, 74. [CrossRef]

23. Al Awaidy, S.A.; Bawikar, S.; Al Busaidy, S.; Baqiani, S.; Al Abedani, I.; Varghese, R.; Abdoan, H.S.; Al Abdoon, H.; Bhatnagar, S.; Al Hasini, K.S. Considerations for introduction of a rotavirus vaccine in Oman: Rotavirus disease and economic burden. J. Infect. Dis. 2009, 200 (Suppl. 1), S248-S253. [CrossRef]

24. Jafari, F.; Garcia-Gil, L.J.; Salmanzadeh-Ahrabi, S.; Shokrzadeh, L.; Aslani, M.M.; Pourhoseingholi, M.A.; Derakhshan, F.; Zali, M.R. Diagnosis and prevalence of enteropathogenic bacteria in children less than 5 years of age with acute diarrhea in Tehran children's hospitals. J. Infect. 2009, 58, 21-27. [CrossRef]

25. Saeed, A.; Abd, H.; Sandstrom, G. Microbial aetiology of acute diarrhoea in children under five years of age in Khartoum, Sudan. J. Med. Microbiol. 2015, 64, 432-437. [CrossRef]

26. Al-Kubaisy, W.; Al Badre, A.; Al-Naggar, R.A.; Shamsidah, N.N. Epidemiological study of bloody diarrhoea among children in Baghdad, Iraq. Int. Arch. Med. 2015, 8. [CrossRef]

27. Al-Freihi, H.; Twum-Danso, K.; Sohaibani, M.; Bella, H.; el-Mouzan, M.; Sama, K. The microbiology of acute diarrhoeal disease in the eastern province of Saudi Arabia. East Afr. Med. J. 1993, 70, 267-269.

28. El-Sheikh, S.M.; el-Assouli, S.M. Prevalence of viral, bacterial and parasitic enteropathogens among young children with acute diarrhoea in Jeddah, Saudi Arabia. J. Health Popul. Nutr. 2001, 19, 25-30.

29. Al Ayed, M.S.; Asaad, A.; Mahdi, A.; Qureshi, M. Aetiology of acute gastroenteritis in children in Najran region, Saudi Arabia. J. Health Spec. 2013, 1, 84-89. [CrossRef] 
30. Ismaeel, A.Y.; Jamsheer, A.E.; Yousif, A.Q.; Al-Otaibi, M.A.; Botta, G.A. Causative pathogens of severe diarrhea in children. Saudi Med. J. 2002, 23, 1064-1069.

31. Sethi, S.K.; Khuffash, F.A.; al-Nakib, W. Microbial etiology of acute gastroenteritis in hospitalized children in Kuwait. Pediatr. Infect. Dis. J. 1989, 8, 593-597. [CrossRef]

32. Aithala, G.; Al Dhahry, S.H.; Saha, A.; Elbualy, M.S. Epidemiological and clinical features of rotavirus gastroenteritis in Oman. J. Trop. Pediatr. 1996, 42, 54-57. [CrossRef]

33. Al-Thani, A.; Baris, M.; Al-Lawati, N.; Al-Dhahry, S. Characterising the aetiology of severe acute gastroenteritis among patients visiting a hospital in Qatar using real-time polymerase chain reaction. BMC Infect. Dis. 2013, 13, 329. [CrossRef] [PubMed]

34. Mubashir, M.; Khan, A.; Baqai, R.; Iqbal, J.; Ghafoor, A.; Zuberi, S.; Burney, M.I. Causative agents of acute diarrhoea in the first 3 years of life: Hospital-based study. J. Gastroenterol. Hepatol. 1990, 5, 264-270. [PubMed]

35. Pazzaglia, G.; Bourgeois, A.L.; Mourad, A.S.; Iqbal, J.; Ghafoor, A.; Zuberi, S.; Burney, M.I. Campylobacter diarrhea in Alexandria, Egypt. J. Egypt. Public Health Assoc. 1995, 70, 229-241. [PubMed]

36. El-Mohamady, H.; Abdel-Messih, I.A.; Youssef, F.G.; Said, M.; Farag, H.; Shaheen, H.I.; Rockabrand, D.M.; Luby, S.B.; Hajjeh, R.; Sanders, J.W.; et al. Enteric pathogens associated with diarrhea in children in Fayoum, Egypt. Diagn. Microbiol. Infect. Dis. 2006, 56, 1-5. [CrossRef] [PubMed]

37. Al Jarousha, A.M.; El Jarou, M.A.; El Qouqa, I.A. Bacterial enteropathogens and risk factors associated with childhood diarrhea. Indian J. Pediatr. 2011, 78, 165-170. [CrossRef] [PubMed]

38. Mikhail, I.A.; Fox, E.; Haberberger, R.L.; Ahmed, M.H.; Abbatte, E.A. Epidemiology of bacterial pathogens associated with infectious diarrhea in Djibouti. J. Clin. Microbiol. 1990, 28, 956-961.

39. Casalino, M.; Yusuf, M.W.; Nicoletti, M.; Bazzicalupo, P.; Coppo, A.; Colonna, B.; Cappelli, C.; Bianchini, C.; Falbo, V.; Ahmed, H.J.; et al. A two-year study of enteric infections associated with diarrhoeal diseases in children in urban Somalia. Trans. R. Soc. Trop. Med. Hyg. 1988, 82, 637-641. [CrossRef]

40. Rahouma, A.; Klena, J.D.; Krema, Z.; Abobker, A.A.; Treesh, K.; Franka, E.; Abusnena, O.; Shaheen, H.I.; El Mohammady, H.; Abudher, A.; et al. Enteric pathogens associated with childhood diarrhea in Tripoli-Libya. Am. J. Trop. Med. Hyg. 2011, 84, 886-891. [CrossRef]

41. Nejma, I.B.S.B.; Zaafrane, M.H.; Hassine, F.; Sdiri-Loulizi, K.; Ben Said, M.; Aouni, M.; Mzoughi, R. Etiology of Acute Diarrhea in Tunisian Children with Emphasis on Diarrheagenic Escherichia coli: Prevalence and Identification of E. coli Virulence Markers. Iran. J. Public Health 2014, 43, 947-960.

42. Youssef, M.; Shurman, A.; Bougnoux, M.; Rawashdeh, M.; Bretagne, S.; Strockbine, N. Bacterial, viral and parasitic enteric pathogens associated with acute diarrhea in hospitalized children from northern Jordan. FEMS Immunol. Med. Microbiol. 2000, 28, 257-263. [CrossRef]

43. Benmessaoud, R.; Jroundi, I.; Nezha, M.; Moraleda, C.; Tligui, H.; Seffar, M.; Alvarez-Martínez, M.J.; Pons, M.J.; Chaacho, S.; Hayes, E.B.; et al. Aetiology, epidemiology and clinical characteristics of acute moderate-to-severe diarrhoea in children under 5 years of age hospitalized in a referral paediatric hospital in Rabat, Morocco. J. Med. Microbiol. 2015, 64, 84-92. [CrossRef] [PubMed]

44. Achtman, M.; Wain, J.; Weill, F.X.; Nair, S.; Zhou, Z.; Sangal, V.; Krauland, M.G.; Hale, J.L.; Harbottle, H.; Uesbeck, A.; et al. Multilocus sequence typing as a replacement for serotyping in Salmonella enterica. PLoS Pathog. 2012, 8, e1002776. [CrossRef] [PubMed]

45. Spector, M.P.; Kenyon, W.J. Resistance and survival strategies of Salmonella enterica to environmental stresses. Food Res. Int. 2012, 45, 455-481. [CrossRef]

46. Xu, H.; Lee, H.Y.; Ahn, J. Cross-protective effect of acid-adapted Salmonella enterica on resistance to lethal acid and cold stress conditions. Lett. Appl. Microbiol. 2008, 47, 290-297. [CrossRef] [PubMed]

47. Jarvis, N.A.; O’Bryan, C.A.; Dawoud, T.M.; Park, S.H.; Kwon, Y.M.; Crandall, G.P.; Ricke, S.C. An overview of Salmonella thermal destruction during food processing and preparation. Food Control 2016, 68, 280-290. [CrossRef]

48. Yang, Y.; Khoo, W.J.; Zheng, Q.; Chung, H.J.; Yuk, H.G. Growth temperature alters Salmonella Enteritidis heat/acid resistance, membrane lipid composition and stress/virulence related gene expression. Int. J. Food Microbiol. 2014, 172, 102-109. [CrossRef] [PubMed]

49. Manios, S.G.; Skandamis, P.N. Effect of frozen storage, different thawing methods and cooking processes on the survival of Salmonella spp. and Escherichia coli O157:H7 in commercially shaped beef patties. Meat Sci. 2015, 101, 25-32. [CrossRef] 
50. Simpson Beauchamp, C.; Byelashov, O.A.; Geornaras, I.; Kendall, P.A.; Scanga, J.A.; Belk, K.E.; Smith, G.C.; Sofos, J.N. Fate of Listeria monocytogenes during freezing, thawing and home storage of frankfurters. Food Microbiol. 2010, 27, 144-149. [CrossRef]

51. Islam, M.; Morgan, J.; Doyle, M.P.; Phatak, S.C.; Millner, P.; Jiang, X. Fate of Salmonella enterica serovar Typhimurium on carrots and radishes grown in fields treated with contaminated manure composts or irrigation water. Appl. Environ. Microbiol. 2004, 70, 2497-2502. [CrossRef]

52. Levantesi, C.; Bonadonna, L.; Briancesco, R.; Grohmann, E.; Toze, S.; Tandoi, V. Salmonella in surface and drinking water: Occurrence and water-mediated transmission. Food Res. Int. 2012, 45, 587-602. [CrossRef]

53. Gordon, M.A. Salmonella infections in immunocompromised adults. J. Infect. 2008, 56, 413-422. [CrossRef] [PubMed]

54. Eng, S.-K.; Pusparajah, P.; Ab Mutalib, N.-S.; Ser, H.-L.; Chan, K.-G.; Lee, L.-H. Salmonella: A review on pathogenesis, epidemiology and antibiotic resistance. Front. Life Sci. 2015, 8, 284-293. [CrossRef]

55. Fabrega, A.; Vila, J. Salmonella enterica serovar Typhimurium skills to succeed in the host: Virulence and regulation. Clin. Microbiol. Rev. 2013, 26, 308-341. [CrossRef] [PubMed]

56. Hohmann, E.L. Nontyphoidal salmonellosis. Clin. Infect. Dis. 2001, 32, 263-269. [PubMed]

57. Jones, T.F.; Ingram, L.A.; Cieslak, P.R.; Vugia, D.J.; Tobin-D'Angelo, M.; Hurd, S.; Medus, C.; Cronquist, A.; Angulo, F.J. Salmonellosis outcomes differ substantially by serotype. J. Infect. Dis. 2008, 198, 109-114. [CrossRef]

58. Chen, H.M.; Wang, Y.; Su, L.H.; Chiu, C.H. Nontyphoid Salmonella infection: Microbiology, clinical features, and antimicrobial therapy. Pediatr. Neonatol. 2013, 54, 147-152. [CrossRef] [PubMed]

59. Crump, J.A.; Sjolund-Karlsson, M.; Gordon, M.A.; Parry, C.M. Epidemiology, clinical presentation, laboratory diagnosis, antimicrobial resistance, and antimicrobial management of invasive Salmonella infections. Clin. Microbiol. Rev. 2015, 28, 901-937. [CrossRef] [PubMed]

60. Sanchez-Vargas, F.M.; Abu-El-Haija, M.A.; Gomez-Duarte, O.G. Salmonella infections: An update on epidemiology, management, and prevention. Travel Med. Infect. Dis. 2011, 9, 263-277. [CrossRef]

61. Sirinavin, S.; Chiemchanya, S.; Vorachit, M. Systemic nontyphoidal Salmonella infection in normal infants in Thailand. Pediatr. Infect. Dis. J. 2001, 20, 581-587. [CrossRef]

62. Majowicz, S.E.; Musto, J.; Scallan, E.; Angulo, F.J.; Kirk, M.; O’Brien, S.J.; Jones, T.F.; Fazil, A.; Hoekstra, R.M. International Collaboration on Enteric Disease 'Burden of Illness' Studies. The global burden of nontyphoidal Salmonella gastroenteritis. Clin. Infect. Dis. 2010, 50, 882-889. [CrossRef]

63. WHO. Salmonella (Non-Typhoidal). Available online: https://www.who.int/en/news-room/fact-sheets/detail/ salmonella-(non-typhoidal) (accessed on 5 February 2018).

64. Kirk, M.D.; Pires, S.M.; Black, R.E.; Caipo, M.; Crump, J.A.; Devleesschauwer, B.; Döpfer, D.; Fazil, A.; Fischer-Walker, C.L.; Hald, T;; et al. World Health Organization Estimates of the Global and Regional Disease Burden of 22 Foodborne Bacterial, Protozoal, and Viral Diseases, 2010: A Data Synthesis. PLoS Med. 2015, 12, e1001921.

65. Farag, E.; Garcell, H.G.; Ganesan, N.; Ahmed, S.N.; Al-Hajri, M.; Al Thani, S.M.; Al-Marri, S.A.; Ibrahim, E.; Al-Romaihi, H.E. A retrospective epidemiological study on the incidence of salmonellosis in the State of Qatar during 2004-2012. Qatar Med. J. 2016, 2016, 3.

66. Malaeb, M.; Bizri, A.R.; Ghosn, N.; Berry, A.; Musharrafieh, U. Salmonella burden in Lebanon. Epidemiol. Infect. 2016, 144, 1761-1769. [CrossRef]

67. Gargouri, N.; Walke, H.; Belbeisi, A.; Hadadin, A.; Salah, S.; Ellis, A.; Braam, H.P.; Angulo, F.J. Estimated burden of human Salmonella, Shigella, and Brucella infections in Jordan, 2003-2004. Foodborne Pathog. Dis. 2009, 6, 481-486. [CrossRef] [PubMed]

68. al-Rajab, W.J.; Abdullah, B.A.; Shareef, A.Y. Salmonella responsible for infantile gastroenteritis in Mosul, Iraq. J. Trop. Med. Hyg. 1988, 91, 315-318. [PubMed]

69. Al-Gallas, N.; Bahri, O.; Bouratbeen, A.; Ben Haasen, A.; Ben Aissa, R. Etiology of acute diarrhea in children and adults in Tunis, Tunisia, with emphasis on diarrheagenic Escherichia coli: Prevalence, phenotyping, and molecular epidemiology. Am. J. Trop. Med. Hyg. 2007, 77, 571-582. [CrossRef] [PubMed]

70. Hegazi, M.A.; Patel, T.A.; El-Deek, B.S. Prevalence and characters of Entamoeba histolytica infection in Saudi infants and children admitted with diarrhea at 2 main hospitals at South Jeddah: A re-emerging serious infection with unusual presentation. Braz. J. Infect. Dis. 2013, 17, 32-40. [CrossRef] [PubMed] 
71. Ravel, A.; Smolina, E.; Sargeant, J.M.; Cook, A.; Marshall, B.; Fleury, M.D.; Pollari, F. Seasonality in human salmonellosis: Assessment of human activities and chicken contamination as driving factors. Foodborne Pathog. Dis. 2010, 7, 785-794. [CrossRef] [PubMed]

72. Ashtiani, M.T.; Monajemzadeh, M.; Kashi, L. Trends in antimicrobial resistance of fecal Shigella and Salmonella isolates in Tehran, Iran. Indian J. Pathol. Microbiol. 2009, 52, 52-55.

73. Taha, R.R.; Alghalibi, S.M.; Saeedsaleh, M.G. Salmonella spp. in patients suffering from enteric fever and food poisoning in Thamar city, Yemen. East. Mediterr. Health J. 2013, 19, 88-93. [CrossRef]

74. Mikhail, I.A.; Hyams, K.C.; Podgore, J.K.; Haberberger, R.L.; Boghdadi, A.M.; Mansour, N.S.; Woody, J.N. Microbiologic and clinical study of acute diarrhea in children in Aswan, Egypt. Scand. J. Infect. Dis. 1989, 21, 59-65. [CrossRef] [PubMed]

75. El-Shabrawi, M.; Salem, M.; Abou-Zekri, M.; El-Naghi, S.; Hassanin, F.; El-Adly, T.; El-Shamy, A. The burden of different pathogens in acute diarrhoeal episodes among a cohort of Egyptian children less than five years old. Prz. Gastroenterol. 2015, 10, 173-180. [CrossRef]

76. Ranjbar, R.; Giammanco, G.M.; Farshad, S.; Owlia, P.; Aleo, A.; Mammina, C. Serotypes, antibiotic resistance, and class 1 integrons in Salmonella isolates from pediatric cases of enteritis in Tehran, Iran. Foodborne Pathog. Dis. 2011, 8, 547-553. [CrossRef] [PubMed]

77. Battikhi, M.N. Epidemiological study on Jordanian patients suffering from diarrhoea. New Microbiol. 2002, 25, 405-412. [PubMed]

78. Ali, M.B.; Ghenghesh, K.S.; Aissa, R.B.; Abuhelfaia, A.; Dufani, M. Etiology of childhood diarrhea in Zliten, Libya. Saudi Med. J. 2005, 26, 1759-1765. [PubMed]

79. Aiat Melloul, A.; Hassani, L. Salmonella infection in children from the wastewater-spreading zone of Marrakesh city (Morocco). J. Appl. Microbiol. 1999, 87, 536-539. [CrossRef]

80. Ramadan, F.; Unni, A.G.; Hablas, R.; Rizk, M.S. Salmonella-induced enteritis. Clinical, serotypes and treatment. J. Egypt. Public Health Assoc. 1992, 67, 357-367.

81. Adam, M.A.; Wang, J.; Enan, K.A.; Shen, H.; Wang, H.; El Hussein, A.R.; Musa, A.B.; Khidir, I.M.; Ma, X. Molecular Survey of Viral and Bacterial Causes of Childhood Diarrhea in Khartoum State, Sudan. Front. Microbiol. 2018, 9, 112. [CrossRef]

82. Hendriksen, R.S.; Vieira, A.R.; Karlsmose, S.; Lo Fo Wong, D.M.; Jensen, A.B.; Wegener, H.C.; Aarestrup, F.M. Global monitoring of Salmonella serovar distribution from the World Health Organization Global Foodborne Infections Network Country Data Bank: Results of quality assured laboratories from 2001 to 2007. Foodborne Pathog. Dis. 2011, 8, 887-900. [CrossRef]

83. Galanis, E.; Wong, D.M.L.F.; Patrick, M.E.; Binsztein, N.; Cieslik, A.; Chalermchikit, T.; Aidara-Kane, A.; Ellis, A.; Angulo, F.J.; Wegener, H.C.; et al. Web-based surveillance and global Salmonella distribution, 2000-2002. Emerg. Infect. Dis. 2006, 12, 381-388. [CrossRef]

84. Kasimoglu Dogru, A.; Ayaz, N.D.; Gencay, Y.E. Serotype identification and antimicrobial resistance profiles of Salmonella spp. isolated from chicken carcasses. Trop. Anim. Health Prod. 2010, 42, 893-897. [CrossRef]

85. Ayers, L.T.; Williams, I.T.; Gray, S.; Griffin, P.M.; Hall, A.J. Surveillance for Foodborne Disease Outbreaks-United States, 2006. Morb. Mortal. Wkly. Rep. 2009, 58, 609-615. Available online: https://www.cdc.gov/mmwr/preview/mmwrhtml/mm5822a1.htm (accessed on 12 June 2009).

86. Abd-Elghany, S.M.; Sallam, K.I.; Abd-Elkhalek, A.; Tamura, T. Occurrence, genetic characterization and antimicrobial resistance of Salmonella isolated from chicken meat and giblets. Epidemiol. Infect. 2015, 143, 997-1003. [CrossRef]

87. Sodagari, H.R.; Mashak, Z.; Ghadimianazar, A. Prevalence and antimicrobial resistance of Salmonella serotypes isolated from retail chicken meat and giblets in Iran. J. Infect. Dev. Ctries. 2015, 9, 463-469. [CrossRef]

88. Al-Rajab, W.J.; Al-Chalabi, K.A.; Sulayman, S.D. Incidence of Salmonella in poultry and meat products in Iraq. Food Microbiol. 1986, 3, 55-57. [CrossRef]

89. Noori, T.E.; Alwan, M.J. Isolation and identification of zoonotic bacteria from poultry meat. Int. J. Adv. Res. Biol. Sci. 2016, 3, 57-66.

90. Al-Zenki, S.; Al-Nasser, A.; Al-Safar, A.; Alomirah, H.; Al-Haddad, A.; Hendriksen, R.S.; Aarestrup, F.M. Prevalence and antibiotic resistance of Salmonella isolated from a poultry farm and processing plant environment in the state of Kuwait. Foodborne Pathog. Dis. 2007, 4, 367-373. [CrossRef] 
91. Oueslati, W.; Rjeibi, M.R.; Mhadhbi, M.; Jbeli, M.; Zrelli, S.; Ettriqui, A. Prevalence, virulence and antibiotic susceptibility of Salmonella spp. strains, isolated from beef in Greater Tunis (Tunisia). Meat Sci. 2016, 119, 154-159. [CrossRef]

92. al-Nakhli, H.M.; al-Ogaily, Z.H.; Nassar, T.J. Representative Salmonella serovars isolated from poultry and poultry environments in Saudi Arabia. Rev. Sci. Tech. 1999, 18, 700-709. [CrossRef]

93. Ahmed, A.M.; Shimamoto, T. Isolation and molecular characterization of Salmonella enterica, Escherichia coli O157:H7 and Shigella spp. from meat and dairy products in Egypt. Int. J. Food Microbiol. 2014, 168-169, 57-62. [CrossRef]

94. Tarabees, R.; Elsayed, M.S.A.; Shawish, R.; Basiouni, S.; Shehata, A.A. Isolation and characterization of Salmonella Enteritidis and Salmonella Typhimurium from chicken meat in Egypt. J. Infect. Dev. Ctries. 2017, 11, 314-319. [CrossRef]

95. Amajoud, N.; Bouchrif, B.; El Maadoudi, M.; Skalli Senhaji, N.; Karraouan, B.; El Harsal, A.; El Abrini, J. Prevalence, serotype distribution, and antimicrobial resistance of Salmonella isolated from food products in Morocco. J. Infect. Dev. Ctries. 2017, 11, 136-142. [CrossRef]

96. Shah, A.H.; Korejo, N. Antimicrobial resistance profile of Salmonella Serovars isolated from chicken meat. J. Vet. Anim. Sci. 2012, 2, 40-46.

97. Gharieb, R.M.; Tartor, Y.H.; Khedr, M.H. Non-typhoidal Salmonella in poultry meat and diarrhoeic patients: Prevalence, antibiogram, virulotyping, molecular detection and sequencing of class I integrons in multidrug resistant strains. Gut Pathog. 2015, 7, 34. [CrossRef]

98. Soltan-Dallal, M.; Sharifi-Yazdi, M.K.; Mirzaei, N.; Kalantar, E. Prevalence of Salmonella spp. in packed and unpacked red meat and chicken in South of Tehran. Jundishapur J. Microbiol. 2014, 7, e9254. [CrossRef]

99. Malkawi, H. Molecular identification of Salmonella isolates from poultry and meat productsin Irbid City, Jordan. World J. Microbiol. Biotechnol. 2003, 19, 455-459. [CrossRef]

100. Nimri, L.; Abu Al-Dahab, F.; Batchoun, R. Foodborne bacterial pathogens recovered from contaminated shawarma meat in northern Jordan. J. Infect. Dev. Ctries. 2014, 8, 1407-1414. [CrossRef]

101. Jaradat, Z.W.; Abedel Hafiz, L.; Ababneh, M.M.; Ababneh, Q.O.; Al Mousa, W.; Al-Nabulsi, A.; Osaili, T.M.; Holley, R. Comparative analysis of virulence and resistance profiles of Salmonella Enteritidis isolates from poultry meat and foodborne outbreaks in northern Jordan. Virulence 2014, 5, 601-610. [CrossRef]

102. El Shrek, Y.M.; Ali, M.R. Microbiological study of spiced chicken burgers in Tripoli City, Libya. East. Mediterr. Health J. 2012, 18, 653-662. [CrossRef]

103. Soomro, A.H.; Khaskheli, M.; Bhutto, B.; Shah, G.; Azizullah, M.; Dewani, P. Prevalence and antimicrobial resistance of Salmonella serovars isolated from poultry meat in Hyderabad, Pakistan. Turk. J. Vet. Anim. Sci. 2010, 34, 455-460.

104. El Hussein, A.; Elmadiena, M.M.; Elsaid, S.; Siddig, M.; Muckle, C.A.; Cole, L.; Wilkie, E.; Mistry, K.; Perets, A. Prevalence of Salmonella enterica subspecies enterica serovars in Khartoum State, Sudan. Res. J. Microbiol. 2010, 5, 966-973. [CrossRef]

105. Hasan, S. Investigation of Salmonella in Retail Raw Meat in Syria. J. Agric. Chem. Biotech. 2013, 4, 147-153.

106. Abbassi-Ghozzi, I.; Jaouani, A.; Hammami, S.; Martinez-Urtaza, J.; Boudabous, A.; Gtari, M. Molecular analysis and antimicrobial resistance of Salmonella isolates recovered from raw meat marketed in the area of "Grand Tunis", Tunisia. Pathol. Biol. 2012, 60, e49-e54. [CrossRef] [PubMed]

107. Khan, M.A.; Suryanarayan, P.; Ahmed, M.M.; Vaswani, R.B.; Faheem, S.M. Antimicrobial susceptibility of Salmonella isolates from chicken meat samples in Dubai, United Arab Emirates. Int. J. Food Nutr. Public Health 2010, 3, 149-159.

108. Ozdemir, K.; Acar, S. Plasmid profile and pulsed-field gel electrophoresis analysis of Salmonella enterica isolates from humans in Turkey. PLoS ONE 2014, 9, e95976. [CrossRef] [PubMed]

109. Chang, Y.C.; Scaria, J.; Ibraham, M.; Doiphode, S.; Chang, Y.F.; Sultan, A.; Mohammed, H.O. Distribution and factors associated with Salmonella enterica genotypes in a diverse population of humans and animals in Qatar using multi-locus sequence typing (MLST). J. Infect. Public Health 2016, 9, 315-323. [CrossRef] [PubMed]

110. Dyson, Z.A.; Thanh, D.P.; Bodhidatta, L.; Mason, C.J.; Srijan, A.; Rabaa, M.A.; Vinh, P.V.; Thanh, T.H.; Thwaites, G.E.; Baker, S.; et al. Whole genome sequence analysis of Salmonella Typhi isolated in Thailand before and after the introduction of a national immunization program. PLoS Negl. Trop. Dis. 2017, 11, e0005274. [CrossRef] 
111. Pornsukarom, S.; van Vliet, A.H.M.; Thakur, S. Whole genome sequencing analysis of multiple Salmonella serovars provides insights into phylogenetic relatedness, antimicrobial resistance, and virulence markers across humans, food animals and agriculture environmental sources. BMC Genom. 2018, 19, 801. [CrossRef] [PubMed]

112. Kwong, J.C.; Mercoulia, K.; Tomita, T.; Easton, M.; Li, H.Y.; Bulach, D.M.; Stinear, T.P.; Seemann, T.; Howden, B.P. Prospective Whole-genome sequencing enhances national surveillance of Listeria monocytogenes. J. Clin. Microbiol. 2016, 54, 333-342. [CrossRef] [PubMed]

113. Phillips, A.; Sotomayor, C.; Wang, Q.; Holmes, N.; Furlong, C.; Ward, K.; Howard, P.; Octavia, S.; Lan, R.; Sintchenko, V. Whole genome sequencing of Salmonella Typhimurium illuminates distinct outbreaks caused by an endemic multi-locus variable number tandem repeat analysis type in Australia, 2014. BMC Microbiol. 2016, 16, 211. [CrossRef] [PubMed]

114. Kang, M.-S.; Oh, J.-Y.; Kwon, Y.-K.; Lee, D.Y.; Jeong, O.M.; Choi, B.K.; Youn, S.Y.; Jeon, B.W.; Lee, H.J.; Lee, H.S. Public health significance of major genotypes of Salmonella enterica serovar Enteritidis present in both human and chicken isolates in Korea. Res. Vet. Sci. 2017, 112, 125-131. [CrossRef]

115. Cai, Y.; Tao, J.; Jiao, Y.; Fei, X.; Zhou, L.; Wang, Y.; Zheng, H.; Pan, Z.; Jiao, X. Phenotypic characteristics and genotypic correlation between Salmonella isolates from a slaughterhouse and retail markets in Yangzhou, China. Int. J. Food Microbiol. 2016, 222, 56-64. [CrossRef]

116. Thompson, C.K.; Wang, Q.; Bag, S.K.; Franklin, N.; Shadbolt, C.T.; Howard, P.; Fearnley, E.J.; Quinn, H.E.; Sintchenko, V.; Hope, K.G. Epidemiology and whole genome sequencing of an ongoing point-source Salmonella Agona outbreak associated with sushi consumption in western Sydney, Australia 2015. Epidemiol. Infect. 2017, 145, 2062-2071. [CrossRef]

117. Jagadeesan, B.; Gerner-Smidt, P.; Allard, M.W.; Leuillet, S.; Winkler, A.; Xiao, Y.; Leuillet, S.; Winkler, A.; Xiao, Y.; Chaffron, S.; et al. The use of next generation sequencing for improving food safety: Translation into practice. Food Microbiol. 2019, 79, 96-115. [CrossRef]

118. Hur, J.; Jawale, C.; Lee, J.H. Antimicrobial resistance of Salmonella isolated from food animals: A review. Food Res. Int. 2012, 45, 819-830. [CrossRef]

119. Mukerji, S.; O’Dea, M.; Barton, M.; Kirkwood, R.; Lee, T.; Abraham, S. Development and transmission of antimicrobial resistance among Gram-negative bacteria in animals and their public health impact. Essays Biochem. 2017, 61, 23-35. [CrossRef] [PubMed]

120. Yildirim, Y.; Gonulalan, Z.; Pamuk, S.; Ertas, N. Incidence and antibiotic resistance of Salmonella spp. on raw chicken carcasses. Food Res. Int. 2011, 44, 725-728. [CrossRef]

121. Ahmed, A.M.; Shimamoto, T.; Shimamoto, T. Characterization of integrons and resistance genes in multidrug-resistant Salmonella enterica isolated from meat and dairy products in Egypt. Int. J. Food Microbiol. 2014, 189, 39-44. [CrossRef]

122. Jassim, A.M. In-home drug storage and self-medication with antimicrobial drugs in Basrah, Iraq. Oman Med. J. 2010, 25, 79-87. [CrossRef] [PubMed]

123. Kambal, A.M. Antimicrobial susceptibility and serogroups of Salmonella isolates from Riyadh, Saudi Arabia. Int. J. Antimicrob. Agents 1996, 7, 265-269. [CrossRef]

124. Prakash, K.P. Epidemiology and antimicrobial resistance of enteric pathogens in Dhahira Region, Oman. Iran. J. Public Health 2008, 37, 60-69.

125. Jamal, W.Y.; Pal, T.; Rotimi, V.O.; Chugh, T.D. Serogroups and antimicrobial susceptibility of clinical isolates of Salmonella species from a teaching hospital in Kuwait. J. Diarrhoeal Dis. Res. 1998, 16, 180-186. [PubMed]

126. Chen, S.; Zhao, S.; White, D.G.; Schroeder, C.M.; Lu, R.; Yang, H.; McDermott, P.F.; Ayers, S.; Meng, J. Characterization of multiple-antimicrobial-resistant Salmonella serovars isolated from retail meats. Appl. Environ. Microbiol. 2004, 70, 1-7. [CrossRef] [PubMed]

127. Doublet, B.; Schwarz, S.; Kehrenberg, C.; Cloeckaert, A. Florfenicol resistance gene floR is part of a novel transposon. Antimicrob. Agents Chemother. 2005, 49, 2106-2108. [CrossRef]

128. Michael, G.B.; Schwarz, S. Antimicrobial resistance in zoonotic nontyphoidal Salmonella: An alarming trend? Clin. Microbiol. Infect. 2016, 22, 968-974. [CrossRef]

129. Zhu, Y.; Lai, H.; Zou, L.; Yin, S.; Wang, C.; Han, X.; Xia, X.; Hu, K.; He, L.; Zhou, K.; et al. Antimicrobial resistance and resistance genes in Salmonella strains isolated from broiler chickens along the slaughtering process in China. Int. J. Food Microbiol. 2017, 259, 43-51. [CrossRef] 
130. Van, T.T.H.; Nguyen, H.N.K.; Smooker, P.M.; Coloe, P.J. The antibiotic resistance characteristics of non-typhoidal Salmonella enterica isolated from food-producing animals, retail meat and humans in South East Asia. Int. J. Food Microbiol. 2012, 154, 98-106. [CrossRef]

131. Campos, M.J.; Palomo, G.; Hormeño, L.; Herrera-León, S.; Domínguez, L.; Vadillo, S.; Píriz, S.; Quesada, A. Prevalence of quinolone resistance determinants in non-typhoidal Salmonella isolates from human origin in Extremadura, Spain. Diagn. Microbiol. Infect. Dis. 2014, 79, 64-69. [CrossRef]

132. Hopkins, K.L.; Wootton, L.; Day, M.R.; Threlfall, E.J. Plasmid-mediated quinolone resistance determinant qnrS1 found in Salmonella enterica strains isolated in the, UK. J. Antimicrob. Chemother. 2007, 59, 1071-1075. [CrossRef]

133. Herrera-Leon, S.; Gonzalez-Sanz, R.; Herrera-Leon, L.; Echeita, M.A. Characterization of multidrug-resistant Enterobacteriaceae carrying plasmid-mediated quinolone resistance mechanisms in Spain. J. Antimicrob. Chemother. 2011, 66, 287-290. [CrossRef]

134. Zhao, S.; Blickenstaff, K.; Glenn, A.; Ayers, S.L.; Friedman, S.L.; Abbott, J.W.; McDermott, P.F. Beta-Lactam resistance in Salmonella strains isolated from retail meats in the United States by the National Antimicrobial Resistance Monitoring System between 2002 and 2006. Appl. Environ. Microbiol. 2009, 75, 7624-7630. [CrossRef] [PubMed]

135. Rotimi, V.O.; Jamal, W.; Pal, T.; Sonnevend, A.; Dimitrov, T.S.; Albert, M.J. Emergence of multidrug-resistant Salmonella spp. and isolates with reduced susceptibility to ciprofloxacin in Kuwait and the United Arab Emirates. Diagn. Microbiol. Infect. Dis. 2008, 60, 71-77. [CrossRef] [PubMed]

(C) 2019 by the authors. Licensee MDPI, Basel, Switzerland. This article is an open access article distributed under the terms and conditions of the Creative Commons Attribution (CC BY) license (http://creativecommons.org/licenses/by/4.0/). 